Surya Lestari, Syahrial, Language skills, sub-skills and...

\title{
LANGUAGE SKILLS, SUB-SKILLS AND VOCABULARIES NEEDED BY AUTOMOTIVE DEPARTMENT STUDENTS OF TECHNICAL HIGH SCHOOL: A NEED ANALYSIS STUDY
}

\author{
Surya Lestari
}

\author{
Syahrial
}

\author{
Bambang Suwarno
}

Universitas Bengkulu

Jalan W.R. Supratman Bengkulu

Email: suryalestari0902@gmail.com

\begin{abstract}
This study aimed to analyze specific English language skills and kind of technical vocabulary that are needed by the third year automotive students of SMKN 2 Kota Bengkulu. The sample for interview comprised of 12 alumni, they were teachers and various company officers who have a MOU with SMKN 2 Kota Bengkulu. In the interview was used saturation sample. The results of interview with alumni indicate that the English skill most needed in the workplace is reading, the second was speaking, the third was writing and the last place was listening. The automotive students/ alumni need to comprehend the technical terms associated with technical terms in English. Related to car, are kick lever, oil pump, water cooling system, trail and rolling roof. Related to heavy machine are rear body offset, over hung, road clearance, light van and rear engine. Related to motorcycle are swing arm, bottom link fork, drum brake and kick starter. General automotive vocabulary are disc brake, gasoline, head lamp, piston and tire. Mastery of technical terms greatly affect the practice of industrial work (prakerin) of students in the work place.
\end{abstract}

Keywords: English language skill, automotive department students, technical terms

\section{INTRODUCTION}

Nunan, in Basturkmen (2010: 1), says that the basic insight that language can be thought of as a tool for communication rather than as sets of phonological, grammatical and lexical items to be memorized led to the notion of developing learning programs to reflect the different communicative needs of disparate groups of learners. Evans and St John (2010, quoted in Basturkmen), if ESP has sometimes moved away from trends in general ELT, it has always retained its emphasis on practical outcomes. We will see that the main concerns of ESP have always been, and remain, with needs analysis, text analysis, and preparing learners to communicate effectively in the tasks prescribed by their study or work situation. Basturmen (2010: 3) concludes that ESP courses are narrower in focus than general ELT courses because they centre on analysis of learners' needs. The statements show that ESP views learners in terms of their work or study roles and that ESP courses focus on work- or study-related needs, not personal needs or general interests. And lastly, there is mention of the fact that ESP involves analysis of texts and language use learners will encounter in their work and study situations. 
Basturkmen (2010: 7) also adds that in an ESP situation, it is understood that the learner would want to achieve 'real world' objectives, objectives requiring specific linguistic competencies. For example, students on an English-for-nursing course may want to 'complete patient records' appropriately or 'interact with patients' in ways that reduce patients' stress. In this situation, language development is seen as the means to the ends but not as the end in itself, and the learners can easily become de-motivated by language course content that does not appear directly relevant to their real world objectives. The ESP teacher/course developer needs to find out what the language-based objectives of the students are in the target occupation or academic discipline and ensure that the content of the ESP course works towards them.

Chambers (2010, quoted in Basturkmen) stated that needs analysis should be concerned with the establishment of communicative needs and their realisations, resulting from an analysis of the communicationin the target situation. Need analysis is important, because the students is generally little aware of his needs. Moreover, it is very important to know the language learning that needed by the students. Hutchinson and Waters (1994: 315) state that the learners' needs should beconsidered in the process of planning the content of a language program. Hutchinson and Waters (2015, quoted in Yassi and Andi), define needs in terms of target need refers to the what the needs to do in the target situation and the learning need that refers to what the learners needs to do in order to learn.

Hutchinson and Waters (2015, quoted in Yassi and Andi), define needs in terms of target need refers to the what the needs to do in the target situation and the learning need that refers to what the learners needs to do in order to learn. They further subcatagorizes target needs into: 1. necessities refers to the type of need due to the demands of the target situation that what the learners have to know in order to function effectively in target situation, that is what the learner has to know in order to function in target situation e.g. a businessman needs to understand business letters, to communicate effectively at sales conference etc. To develop his ability to communicate in the situations, he presumably needs to know the linguistic features such as discourse, function, structure and lexical commonly used in the situations. 2 . Lacks refers to identifying necessity is not enough to describe the needs of particular group of learners. It is also important to recognize what the learners know already, so that we can decide which of the necesseities the learner lacks, in other words, the target proficiency needs macthing against the existing proficiency of learners. 3. wants: identifying necessities and lacks of the learners seems to be an objective sense. This effort must be adapted with the learners' actual motivation in the learning process which may not be ignored. So, taking into account the learners' motivation in language learning process is subjective view needs which is also necessary to employ in the preparation of teaching materials and methodology. A number of ways can be usd to gather information on target needs.

Basturkmen (2010), in the sense of the target situation analysis, discourse analysis, present situation analysis, factor analysis and teaching learner context analysis. He defined that needs analysis in ESP refers to a course development process. In this process the language and skills that the learners will use in their professional targets or workplace or in their vocational study areas are identified and considered in relation to the present state of knowledge of the learners, reviews their perceptions of reviews their needs and the practical possibilities and constraints of the teaching context. 
Evans and St John (2015, quoted in Yassi and Andi), illustrate in figure below about their needs analysis theoritical frameworks:

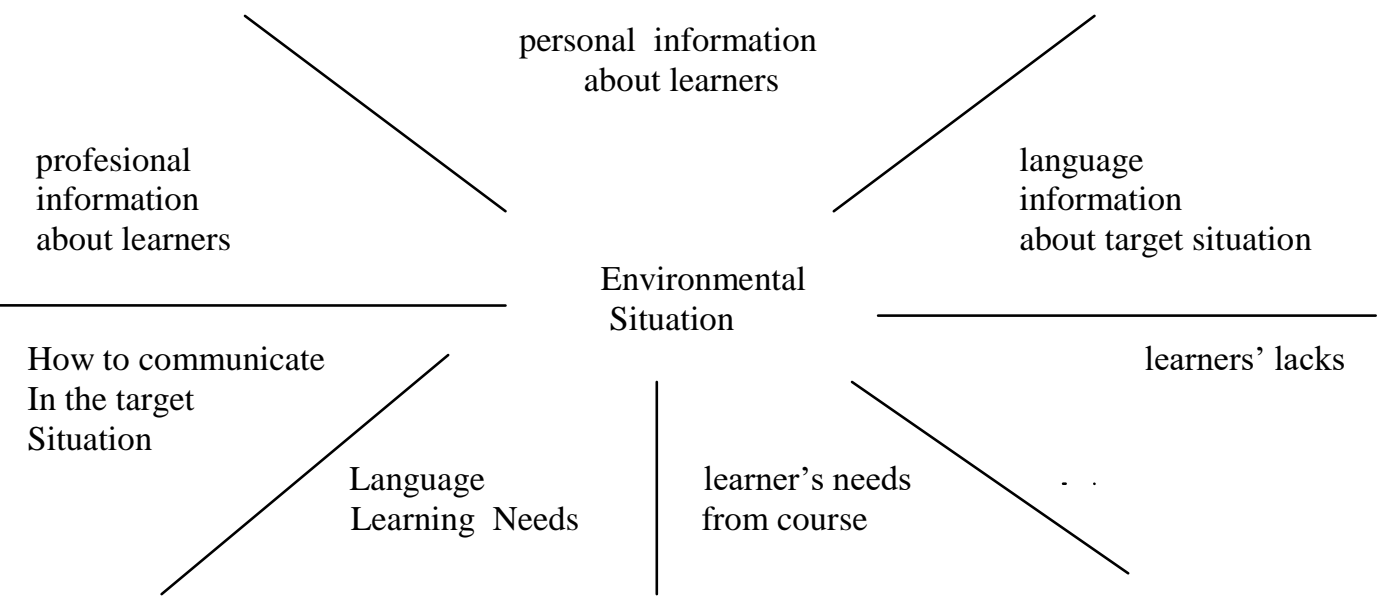

Figure 1. Dudley-Evan and St. John needs analysis framework

In fact, from my observation, the language skills and vocabulary contained in the students' textbook used at SMKN 2 Kota Bengkulu do not yet match the students need. For example, sub-skill of writing in Task 8 page 175 is about "Gardening and students are expected to make an instruction text "How to Plant An Orange Tree". In Task 10 and 11 are the students asked to rewrite the text "Rendang, a Minangkabau Signature Dish". The materials describe for sub-skill listening on the task 1 and 2 page 169 is instruction "How to Make a Pizza". In the task 7 page 174 is instruction "How to Insert the SIM Card Into the Cellphone". Vocabulary used in materials for warming up on the point "Easy Does It" page 167 and page 179 Task 12 are how to match the food on the left side with the recipe and the picture on the right side are not suitable for technical high school students of automotive department.

There have been several studies conducted authors on need analysis for automotive department students such as by Habbash (2014), Evangeline and Ganesh (2015) and Kamin et al (2013). The finding of Habbash (2014)'s study revealed that there are some real special English language needs and interests of students in engineering faculty at the University of Tabuk. These needs motivate students to learn and build their self -confidence towards the learning process. It is recommended that curriculum designers make use of the resulting identifying these needs and to conduct similar studies for other specializations in Saudi Arabia and further afield.

Evangeline and Ganesh (2015). They were conducted to A need analysis of technical writing skill of engineering students in India. The development of Science and Technology has bolstered the use of English Language around the world. This study analyzed the need to teach technical writing as a course to students of technical education in order to make them competent in academics and later in their work place. A course was designed and tried to improve technical writing skill of students of higher education. Though the material used helped them to improve various skills, the main focus was more on the mechanics of writing, the appropriate structure and accuracy. Undertaking more of reading tasks, assignments and presentations will help them in improving their technical writing skill. The effectiveness of the course was evaluated based on oral feedback, and questionnaires after the course. $80 \%$ of the students wanted this course to be incorporated in their curriculum, as an ESP course, as it is more relevant for their immediate needs. 
Kamin et al (2013) adreessed to explore and compare the needs of automotive industries and the educational approaches employed to produce highly skilled workers in both countries. A mixed method research approach was used to develop an insight to stakeholders' perspectives: students, educators and employers. The findings provide an insight of the stakeholders' view of a variety of needs; commensurate in developing a technician labour force. The key issues include the update of training facilities, relevance of curriculum content, technological advancement in the automotive industry, and collaboration between educational institutions and the automotive industry. The study also identified gaps in the qualifications and experiences of teacher: especially inadequate experience, knowledge and skills with current technologies for the automotive industry. On this issue of imperatives for economic growth, the programs reviewed in this study in both Malaysia and Australia are commercial activities designed for profit of the training providers and the automotive industries. The best practices from the training providers could be improved by directly involving stakeholders in the curriculum design activities. This may include implementing customized programs that support local priorities; economic, social and environmental.

Based on the result of the relevant studies above, it can be concluded that some studies on need analysis for automotive engineering have been already conducted but these studies only focussed on students' interest and motivation, writting skill and teachers competence and none of this focussed on language skills, sub-skill and vocabulary . This study aims to analyze the language skills and sub-skills and the kind of technical vocabulary are needed by the third year automotive students of SMKN2 Kota Bengkulu. In particular, this research plants to answer two questions:

1. What language skills are needed by the third year Automotive students of SMKN2 Kota Bengkulu?

2. What language sub-skills are needed by the third year Automotive students of SMKN2 Kota Bengkulu?

3. What vocabularies are needed by the third year Automotive students of SMKN2 Kota Bengkulu?

\section{THIS STUDY}

This research used research and development (R\&D). Sugiyono states that Research and Development is a research method that is used to produce a specific product and test the effectiveness of these products (2009: 297). To be able to produce certain products that are used research needs analysis and to test the effectiveness of these products in order to function in society at large, the necessary research to test the effectiveness of the product. Thus, longitudinal research and development (could gradually multy years). This study only identified and described the language skills, sub-skills and vocabularies needed by the third year automotive students of SMKN 2 Kota Bengkulu.

The data of interview collected through used saturation sample. Charmaz (2010, quoted in Mason), suggests that the aims of the study are the ultimate driver of the project design, and therefore the sample size. She suggests that a small study with "modest claims" might achieve saturation quicker than a study that is aiming to describe a process that spans disciplines (for example describing drug addiction in a specific group rather than a description of general addiction). The sample for interview of this research were the alumni of technical high school who has worked in workshop and which has been officially a MOU with SMKN 2 Kota Bengkulu as well as with teachers earning teaching in the department of automotive SMKN 2 Kota Bengkulu. 
Table 1. Respondents for the research

\begin{tabular}{|c||l||c||c||}
\hline No & \multicolumn{1}{|c||}{ Group of Respondents } & Number & \% \\
\hline \hline 1. & Alumni of automotive student & 6 & 50 \\
\hline 2. & $\begin{array}{l}\text { English Teacher who teach at } \\
\text { Automotive Department }\end{array}$ & 3 & 25 \\
\hline 3. & Productive Department Teacher & 3 & 25 \\
\hline & Total & 12 & $100 \%$ \\
\hline
\end{tabular}

\section{FINDINGS AND DISCUSSION}

Based on response to the question interview part I (General Information) no.1 on Figure 2, it is concluded that the students/ alumni of automotive require English skills for almost all the components of automotive tools in English, especially technical English. This means that English language skills strongly support the work of alumni who work in the automotive world/ automotive industry. Below the percentage of automotive require English skills for almost all the components of automotive tools in English, especially technical English.

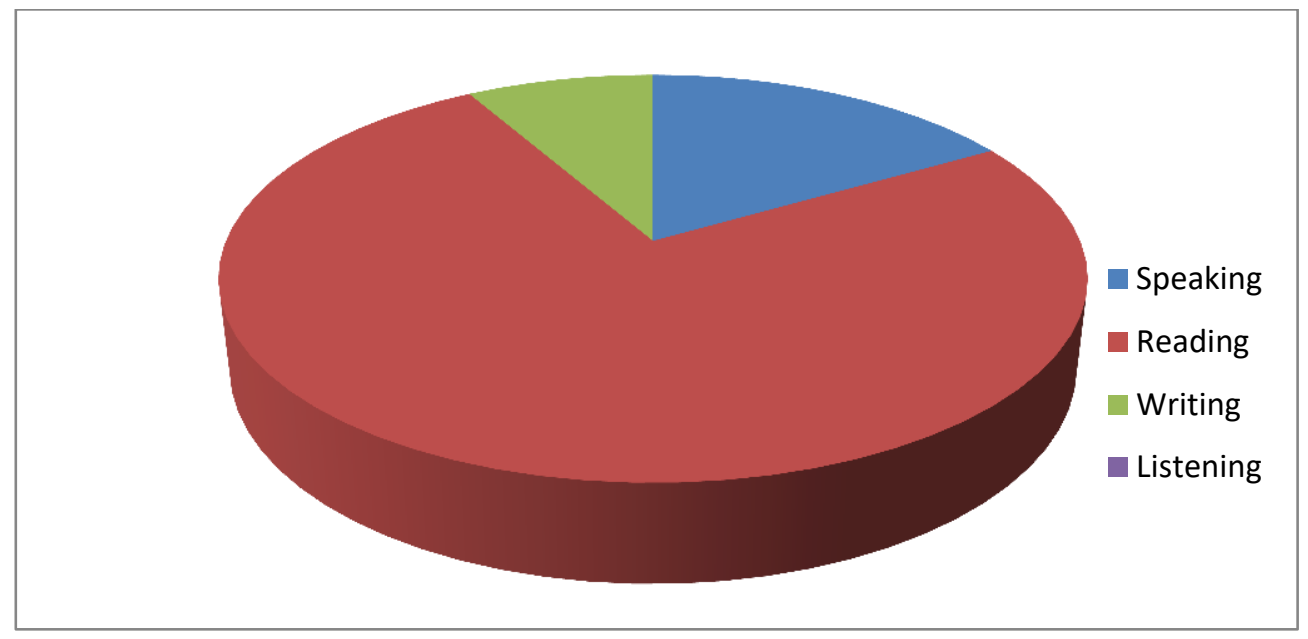

Figure 2. Diagram the English skills needed by the alumni of automotive students

Figure 2, shows that $75 \%$ of respondents stated that reading skill is the most dominant English language skill needed by the students/ alumni automotive when working in the automotive industry. The second place is speaking skill for $16,67 \%, 8,33 \%$ writing skill is in the third place and in the last place is $0 \%$ for listening skill.

The interview result in the link between the material taught English in the classroom when Mr/ Mrs school with English skills needed in work place summarized on the table below

Table 2. Link between the material taught English in the classroom with English needed in work place

\begin{tabular}{|c|l|c|c|}
\hline No & \multicolumn{1}{|c|}{ Statement } & F & \% \\
\hline 3. & $\begin{array}{l}\text { According to Mr. / Ms, is there any link between the material taught } \\
\text { English in the classroom when Mr/ Mrs school with English skills } \\
\text { needed in work place of Mr/ Ms today? Give Example! }\end{array}$ & & \\
\hline & Yes & 12 & 100 \\
\hline & No & 0 & 0 \\
\hline
\end{tabular}


From Table 2, the response of the respondents to interview questions Part I no.3 is $100 \%$ confirmed that there was relationship between English lesson which taught at school with English language skills required in the work place of alumni automotive students who worked in the automotive world. For example terms components of a vehicle, the vehicle used in the practice class at school is still old vehicle while the vehicle is in employment are a lot of new vehicles that use terms of new vehicle components.

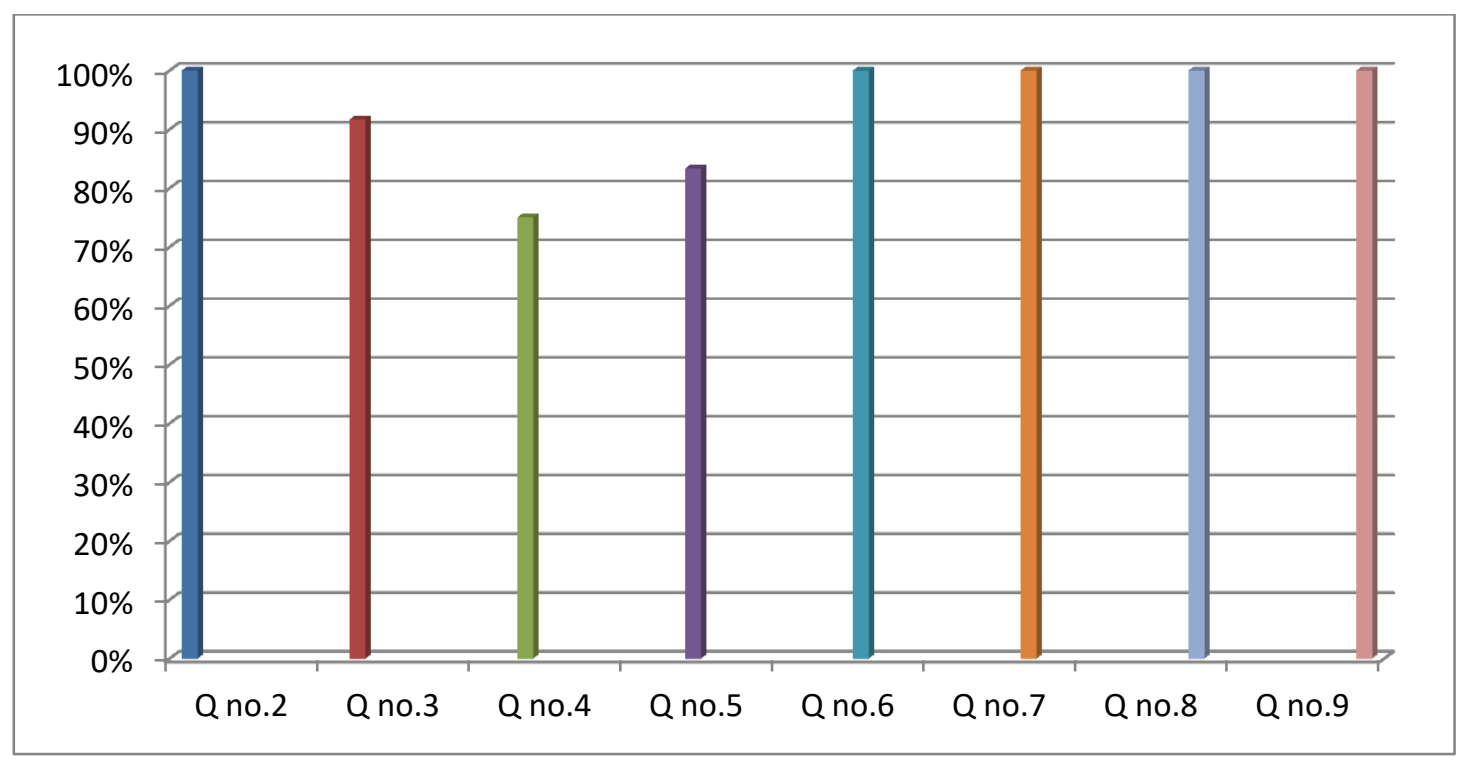

Note: Q no. 2= reading material required $Q$ no. 3= the need of writting activity $\mathrm{Q}$ no.4= the need of speaking activity Q no. 5= the need of listening activity
Q no.6= reading material beside manual book $\mathrm{Q}$ no.7= the need to comprehend technical term Q no.8= the influence mastery English in orally Q no. 9= the influence mastery English in writting

Figure 3. Diagram the English sub-skills activity undertaken by alumni of Automotive students

From Figure 3, the response of the respondents to interview questions Part II no. 2 the conclusion is $100 \%$ the statements of respondents are true about the students/ alumni of automotive require the activities of reading material/ text/ discourse using technical terms in English. The example given, such as manual book, parts catalogs, private catalogs, diagrams, terms of motor variables, modules, data poster, automotive engineering dictionary, job set and booklet about the automotive vocabulary and terminology.

According to Figure 3, the response of the respondents to interview questions Part II no. 3 shows that respondents are given $91,67 \%$ for the need of the automotive students/ alumni towards writing activity using automotive terms in English. Examples of writing activities such as writing damaged vehicle parts and must be repaired, writing daily/ weekly/ monthly reports, indent spare part, the writing section of spare parts and enginee terms related to car products, heavy equipment and motorcycles as well as the names vehicle components.

From Figure 3, the response of the respondents to interview questions Part II no. 4, the respondents are states that $75 \%$ of students/ alumni SMK automotive majors need to do the speaking activities that use automotive terms in English. For example students can recite terms of vehicle components correctly, the training, trouble/ findings in the field, decision/ change of special tools/ parts, and work order. While 8,33\% respondents stated that students do not actually need the speaking activities that use technical terms in English for students who have graduated from automotive technical department because they will get training 
again before becoming a mechanic/ technician at authorized workshop but the students still must understand and can pronounce these terms correctly in English.

Based on Figure 3, the interview questions Part II no.5, shows that respondents of interview are $83,33 \%$ said that students/ alumni of automotive need to do listening activities that use technical terms in English related to automotive majors, with examples such as briefings, delivery bulletin service, discussions with senior or technician, in the training, key collection, teaching and learning in the classroom, engine scanner command, performance/ practice and listening SOP. 16,67\% stated that the students/ alumni of automotive do not need to do listening activities that use technical terms in English.

From Figure 3, the interview questions Part II no. 6, all of interview respondents stated that English reading materials are required by the automotive students/ alumni beside manual book. Respondents mention that reading materials needed by the students/ alumni automotive beside manual book is part catalogs, the data is posters, books of tool box, technical reports, manual practices (how to use the tool), machine engine, SOP, tapes (how to operate the tools and system of machine work), engineering books reference (heavy equipment, cars and motorcycles), practice of industrial work reports (prakerin), modules and guides service, technical dictionaries and discourse associated with automotive majors.

In Figure 3, the interview questions Part II no. 7, all respondents of the interview also said that the automotive students/ alumni need to comprehend the technical terms associated with technical terms in English. Vocabulary related to car, for example: kick lever, oil pump, water cooling system, trail and rolling roof. Vocabulary related to heavy machine, for example: rear body offset, over hung, road clearance, light van and rear engine. Vocabulary related to motorcycle, for example: swing arm, bottom link fork, drum brake and kick starter. General automotive vocabulary, for example: disc brake, gasoline, head lamp, piston and tire. According to the respondents of the interview, mastery of technical terms is facilitating communication with fellow technician or by the consumer if there are problems in the field (work order), for report generation, the instructions contained in the machine as well as ordering goods (machinery/ equipment) because of technical language with the language of the workshop was not the same.

Based on Figure 3, the interview questions Part II no. 8, 100\% of interview respondents stated that there is influence between the mastery of English technical terms in orally for the students/ alumni SMK majoring in automotive when they practice of industrial work (prakerin). The response interview respondents stated that mastery of the use of technical terms orally, greatly affected the students who practice of industrial work in the practice of industry because the main thing is as a communication tool between technicians with students/ leader, with customers, work orders, performance. So, the students should be true and clear in the pronunciation of the names of the components.

Lastly, based on Figure 3, the interview questions Part II no.9, 100\% of interview respondents stated that there is influence between the mastery of English technical terms in writting for the students/ alumni SMK majoring in automotive when they practice of industrial work (prakerin). Respondents interviewed stated that mastery of the use of technical terms in writing also greatly affected students who practice of industrial work in internships, for example during follow and receive work orders, following the product knowledge, detailing the parts to be replaced and especially when students of make reports. Tus, students must master the written form of the tool component because it will affect the practice in the internship. The technical terms (technical vocabulary) in orallly and written related to basics motorcycle, performance curves, basics of engineering, classification of internal combustion engine, principle gasoline engine system, principle and basic construction machinery system, principle and two stroke engine type system, principle and four stroke engine type system, lubrication system, cooling system, fuel systems, exhaust 
system, power transmission, frame, steering system, suspension system, brake system, wheel and tire, basics of eectricity, system ignition (CDI), charging system, starting system, lighting and signal systems.

\section{DISCUSSION}

The first question in this research is what language skills are needed by the third year automotive students of SMKN 2 Kota Bengkulu. Based on the percentage of the results questionnaire to the students in this study, students indicated that the language skills they need most as an Automotive student in SMKN 2 Kota Bengkulu is speaking in the first place, listening in the second place, reading in the third place and in the last is writing skill. Basturkmen (2010) points out that needs may vary considerably in different disciplines. The teachers/course developers also needed to find out students' perceptions about the importance of academic speaking (learner factor analysis). The teachers/ course developers neglected to investigate how often the students participate in class discussion in their subject classes and the students'perceptions of how important discussion skills are.

Contrary, researcher found different needs of automotive students with alumni of technical students who are already working in the automotive industry. The results of interview with alumni automotive students who has worked in the automotive industry indicated that the most English skill needed in the workplace is reading.

It could be said that there is difference needs in English skills between the third year Automotive students with the alumni of automotive students who has worked in the automotive industry. Robinson, in Basturkmen (2010) argues: The needs that are established for a particular group of students will be an outcome of a needs analysis project and will be influenced by ideological preconceptions of the analysts. A different group of analysts working with the same group of students, but with different views on teaching and learning, would be highly likely to produce a different set of needs.

The second research question is what sub-skills are needed by the third year automotive students of SMKN 2 Kota Bengkulu. The sub-skills of speaking activities needed by students majoring in automotive in SMKN 2 Kota Bengkulu are direct conversations with friends in the department/ teacher/ head technician, discussions with friends in the department/ productive teacher/ head technician, and expressing opinions to the teacher or head technician.

Similarly, the response and the example given by the respondents of the interview. They also state that the student/ alumni SMK majoring in automotive requires speaking skills to support jobs in the automotive world as a means of communication, especially fluency and pronunciation right in terms of vehicle parts in English. Eslami (2010)'s study of the perception between students' and instructors' to English for Academic Purposes (EAP) in Iran. The results show that teachers may therefore need to apply diverse communicative activities in language classrooms to give EAP students opportunities to practice using English in different context and focus more on self-regulated learning.

The sub-skills of listening activities needed by students majoring in automotive SMKN 2 Kota Bengkulu are listening video SOP (Standard Operating Procedure), suggestions/ advice/ notification of teacher/ head technician, and listening to a work order from teacher/ head technician.Respondents of interviews also give the same response to the respondents of questionnaire. They stated that if the students were able to listen to the pronunciation of the terms of components in English then it will be easier for them to work as discussions with fellow technicians, responding to conversations with customers or performance at the time in training. 
Similary, the study of Al-Thiyabi (2014) analyzed students' listening needs and compared the the result to students' exam results and ELI listening objectives. The results showed that teachers should help students identify their listening strategy, strengthen them and create new ones. Ghderpananhi in Al-Thiyabi (2014, p.22) mentioned that teachers should use authentic text in the class. It is the specific evident that using authentic aural text in the specific context it was used, had positive effect on students' processing of listening comprehension.

The sub-skills of reading material that is read by students majoring in automotive SMKN 2 Kota Bengkulu besides manual book are SOP manual book, Field Industrial practice (prakerin)/ daily/ weekly/ monthly reports and reading texts/ context/ references of the machine tool.According to the respondents of the interview, in the automotive industry graduates majoring in automotive vocational doing a lot of reading activities to support the work. This is caused by the development of the automotive industry is very rapid. Moiinvaziri (2014) investigated the perceived English language needs of students in University General English course in Iran. He found that Iranian teachers and curriculum and syllabus designers to consider the importance of the students' real needs and try to develop and design materials which can fullfill the present gap.

The sub-skills of writing activities needed by students majoring in automotive in SMKN 2 Kota Bengkulu are charging and complete the work order, industrial work practice (prakerin)/ daily/ weekly/ monthly reports and booking tools or from consumers. This is similar to the response given by respondents of interviews revealed that students / alumni SMK majoring in automotive requires writing activity using terms of vehicle parts in English because they will be dealing with the reports to be made, the findings in the field or indent spare part. Baig (2012) analyzed the course material of the second language learners. He suggests that teachers need to be aware of what the students need or want from their teaching style to meet the needs of the class in the better way.

The third question in this research is what technical vocabularies are needed by the third year automotive students of SMKN 2 Kota Bengkulu. Based on the questions of interview part II no. 7, 8 and 9, respondents of interview stated that there is influence between the mastery of technical terms in English with the automotive students'/ alumnie' SMK in practice of industrial work report (prakerin) orally and in writing. The technical terms (technical vocabulary) in orallly and written related to basics motorcycle, performance curves, basics of engineering, classification of internal combustion engine, principle gasoline engine system, principle and basic construction machinery system, principle and two stroke engine type system, principle and four stroke engine type system, lubrication system, cooling system, fuel systems, exhaust system, power transmission, frame, steering system, suspension system, brake system, wheel and tire, basics of eectricity, system ignition (CDI), charging system, starting system, lighting and signal systems.

The response given interview respondents stated that mastery of the use of technical terms orallly and written, greatly affected the practice of industrial work of students in the practice of industry because the main thing is as a communication tool between technicians with students/ leader, with customers, work orders, performance, during follow and receive work orders, following the product knowledge, detailing the parts to be replaced and especially when students of make reports.

After make out the result of this study as stated previously in this research and as related to the some theories and previous study, this study has a similarity with the other studies conducted authors on need analysis for automotive department students such as by Habbash (2014), Evangeline and Ganesh (2015) and Kamin et al (2013). Even though having similarity, this study has some differences with others especially in objectives of study. The 
objectives of this study were not only to find out the language skills, sub-skills needed by Automotive students but also more deeply in its components.

Comparing the result of this study with other previous study, this study has strong point. This study has not only focused on finding out the English language skills and subskills but also in each components such as vocabulary needed by Automotive students. So the results of this study are described more deeply and clearly. On the contrary, there are some limitations of this study. This research only analyzed what the most skill, sub-skills must be master and technical vocabulary needed by the third year Automotive students of SMKN 2 Kota Bengkulu.

\section{CONCLUSION}

This study is intended to analyze specific English language skills, sub-skills and kind of technical vocabulary that are needed by the third year automotive students of SMKN2 Kota Bengkulu. The respondents for the questionnaire were all the students level XII SMKN 2 Kota Bengkulu who has thoroughly followed the practice of industrial work (prakerin)/ internship for 3 (three) months at the automotive company which has a MOU with SMKN 2 Kota Bengkulu when they at the grade XI. Addition, the interview data collection, researcher was interviewing graduates of technical high students majoring in automotive that has worked in the automotive company which has authorized workshops and also involves productive teachers and English teachers who taught in the automotive department at SMKN 2 Kota Bengkulu.

Based on the result of this research, it can be concluded that:

1. English skills is very important and needed by the third year Automotive students of SMKN2 Kota Bengkulu and alumni of automotive students. Based on the percentage of the results questionnaire to the students in this study, students indicated that the language skills they need most as a student majoring in automotive in SMKN 2 Kota Bengkulu is speaking in the first place, listening in the second place, reading in the third place and in the last is writing skill.

2. Contrary, researcher found difference needs of students with alumni of technical students who are already working in the automotive industry. The results of interview with alumnie automotive students who has worked in the automotive industry indicate that English skills are most needed in the workplace is reading.

3. Respondents of interview stated that there is influence between the mastery of technical terms in English with the automotive students/ alumni SMK in practice of industrial work report (praktek kerja industri/ prakerin) orally and in writing. The technical terms (technical vocabulary) in orallly and written related to basics motorcycle, performance curves, basics of engineering, classification of internal combustion engine, principle gasoline engine system, principle and basic construction machinery system, principle and two stroke engine type system, principle and four stroke engine type system, lubrication system, cooling system, fuel systems, exhaust system, power transmission, frame, steering system, suspension system, brake system, wheel and tire, basics of eectricity, system ignition (CDI), charging system, starting system, lighting and signal systems.

The educational implication of this study is focused on finding out the English language skills and sub-skills needed by the third year Automotive students of SMKN 2 Kota Bengkulu. developing the quality of the teaching and learning process, for teachers, can be used as a guide in evaluating teaching materials that suit the needs of students. For curriculum designer, can be used as guidelines to adjust the teaching materials to the 
characteristics of the majors that suit the needs of technical high school students. Take a looking at the limitations talk about above, it is also expected for further studies to conduct the research to solve the limitation in this study.

From the result of this study, it is suggested that English teacher to search and know the students precisely what they really need mached to their study program and their future job as technician in automotive industry. This research is expected to help both teacher and students.

\section{BIBLIOGRAFY}

Al-Thiyabi, M.S. (2014). Need analysis for EFL listening skills at AII.mtheyabi@kau.edu.sa, 0508009366

Baig, M. (2012). Need analysis of second language learners with particular regard to their writing skills. IOSR Journal of Humanities and Social Science (JHSS). www.iosrjournals.org

Basturkmen, H. (2010). Developing courses in English for specific purposes. University of Auckland. New Zealand

Eslami, Z. R. (2010). Teachers' voice vs. students' voice: A need analysis approach to English for academic purposes (EAP) in Iran. Department of Teaching,Learning and Culture Texas A\&M University College Station, Texas, USA. email : zeslami@tamu.edu

Evangeline, JCK \& Ganesh, K. (2015). A need analysis of technical writing skill of engineering students in India. Published by EDP Sciences. http://creativecommons.org/licenses/by/4.0/

Habbash, M. M. (2014). Need analysis of engineering students' English needs at the University of Tabuk. Journal of Education and Practice.Vol 5 No.38

Hutchinson, T. \& Torres E. (1994). The textbook as agent of change. ELT journal 48.4. pp. 315-328.

Kamin, Y. (2013). Students perceptions on the relevance of a diploma in an automotive curriculum to the workplace. Published by Elsevier Ltd. Procedia-Social and Behavioral Sciences 9. pp. 90-96

Moiinvaziri, M. (2014). Students' voice: A need analysis of university general English course in Iran. GEMA Online Journal of Language Studies. ISSN: 167-8021

Sugiyono. (2009). Metode penelitian kuantitatif, kualitatif dan R\&D. Bandung: CV Alfabeta

Yassi, A.H. \& Andi K. B. (2015). Syllabus design for English language teaching. Trust Media Publishing. Bantul-Yogyakarta. 